\title{
Social action of syntactic reduplication
}

\author{
Leelo Keevallik* \\ Department of Modern Languages, Box 636, Uppsala University, 75126 Uppsala, Sweden
}

Received 6 December 2008; received in revised form 9 April 2009; accepted 12 August 2009

\begin{abstract}
Reduplication has been shown to carry the semantic meaning of increased intensity, duration or emphasis. This study demonstrates that syntactic reduplication in Estonian is regularly used in responsive positions in action sequences. Instances of syntactic reduplication constitute specific social practices such as affiliative and disaffiliative urging, challenging the prior speaker, reinforcing answers to yes/no questions, and providing a non-elicited confirmation. Syntactic reduplication is a sedimented linguistic pattern grounded in the social actions it recurrently performs. Different reduplicative actions furthermore display characteristic prosodic features, involving initial prominence in affiliative actions and delayed pitch peak in disaffiliative ones. Mock repeats and disconfirming answers are produced with double pitch peaks. Grammar and prosody are complementary means of achieving social action in particular positions in interactive sequences. The paper shows that sequential and social contingencies may be essential in understanding a grammatical pattern.
\end{abstract}

(C) 2009 Elsevier B.V. All rights reserved.

Keywords: Interactional linguistics; Syntactic reduplication; Repetition; Prosody; Action sequences; Estonian

\section{Introduction}

The study of linguistic patterns in relation to social actions has been a growing area of research during the last decades. It resides on the insight that people use language to accomplish meaningful actions while communicating in real time. Linguistic patterns are related to and grounded in the types of social action that they recurrently implement. Many language phenomena can be fully described by accounting for the activity sequences in which they occur (e.g. Goodwin, 1979, 1980, 2007; Fox and Thompson, 1990; Lerner, 1991; Ford, 1993; Ochs et al., 1996; Lindström, A., 1999; Sorjonen, 2001; Couper-Kuhlen and Thompson, 2008). When it comes to language use in interaction, prosody often plays a crucial role in sense-making (Couper-Kuhlen and Selting, 1996; Couper-Kuhlen and Ford, 2004; Golato and Fagyal, 2008). Grammar and prosody together form intricate practices that aim at achieving different communicative actions in specific sequential positions in conversation.

This paper studies a linguistic pattern, syntactic reduplication, and its functioning in conversation, showing that this grammatical phenomenon can only be understood with regard to features of production and in terms of local interactional contingencies. A systematic look at the patterns of syntactic reduplication in Estonian aims at displaying

\footnotetext{
* Tel.: +46 1847113 15; fax: +4618471 1323 .

E-mail address: Leelo.Keevallik@moderna.uu.se.
} 
the import of prosody when combined with a particular grammatical pattern and the intimate connection of grammatical/prosodic constructions to the nature of social action implemented by them.

There are numerous studies on reduplication by linguists who have underlined its iconic nature. It has been stated that more form stands for more content (Haiman, 1980; Lakoff and Johnson, 1980:128). If the speaker repeats something, the utterance will acquire additional meaning. As Moravcsik (1978:316) put it: "(..) reduplicative constructions almost always entail everything that their unreduplicated counterparts do and, in addition, also some thing(s) that their unreduplicated counterparts do not'. When accounting for the universal features of reduplication, she points out that reduplication recurrently expresses increased quantity and amount of emphasis (Moravcsik, 1978:317). Along the same lines, Estonian and Finnish reduplication has been demonstrated to achieve intensification, quantity, and aspectual duration (Erelt and Punttila, 1992, 1993, 1999; Erelt, 1997, 2008). Botha (1988:97, 115-117) who looks at Afrikaans reduplication arrives at the conclusion that there is a unit of semantic content called 'increased' that applies to reduplicative units. The increase may concern emphasis as well as intensity. In a discussion on Hindi reduplication, Abbi (1980) talks about intensification. It has thus always been claimed that reduplication has something to do with increased intensity, emphasis, duration, frequency or quantity cross-linguistically. The iconic explanation therefore sounds plausible. However, even diminution is frequently expressed with reduplication, which has led some linguist to argue against the iconic nature of reduplication (e.g. Kiyomi, 1995). In the Estonian practices discussed below, it could be the case is that two is more emphatic than one would have been. But the iconic value is not the only motivation of using reduplication. Reduplication is regularly implemented to accomplish certain kinds of social action.

Linguistic analyses of reduplication generally focus on the semantics of the construction in isolation, leaving context out of discussion altogether. In contrast, some studies have accounted for reduplication from a pragmatic viewpoint. In a study on Russian reduplication, Israeli (1997:607) argues that it is a device for requesting or promising a higher degree of cooperation. Similarly, Swedish reduplication has been shown to display increased social engagement (Lindström, J., 1999:59, 64-65). In other words, reduplication may be used for displays of personal interests and to satisfy the mutual need of appreciation by interactants.

Even more broadly, different kinds of repetition have been claimed to serve an over-arching need for interpersonal involvement (Tannen, 1987:584). Within the research tradition that acknowledges the centrality of conversation to the functioning of language, repetition has been shown to be used for keeping the floor, showing listenership, providing back-channel responses, stalling, gearing up to answer or speak, humor and play, savoring and showing appreciation of a good line or a good joke, persuasive effect, etc. (Tannen, 1987:583-584). It also establishes coherence in the conversation as a whole (Tannen, 1990:27). In their seminal study on politeness, Brown and Levinson (1987:112-113) claim that repetition of what the interlocutor has just said is a means of achieving positive politeness, it is used to stress emotional agreement with the utterance (or to stress interest and surprise). Nevertheless, the current study will argue that even in the cases where interpersonal involvement may be enhanced by syntactic reduplication, the sequential contexts in which this can be done are restricted. With this particular grammatical device, interpersonal involvement may be displayed in specific sequential positions. The paper will thus add a sequential argument to the discussion on reduplication thus far available in the literature.

Analysis of action sequences has been one of the core subjects of conversation analytic work (as presented comprehensibly in Schegloff, 2007). Conversation analysis has demonstrated that ordinary conversation is finely ordered and that every turn is designed in detail as a response to the previous one(s) (Sacks et al., 1974). Diverging actions will be marked as such and oriented to by the participants in relevant ways. Within this tradition of turn-by-turn analysis of the data, the researchers carefully account for the participants' interpretation of the preceding actions as displayed in subsequent turns. Participants' own analysis of the import of a prior turn is thereby disclosed and seen as an empirical proof of the meaning and function of what the turn accomplished.

The conversation analytic method has already been applied in a study on repetitions, the so-called multiple sayings, whose function is to bring the larger unit of interaction to a halt (Stivers, 2004). By repeating a unit in a multiple saying, the speaker shows that there is no need to continue within the same course of action. Along the same lines, the reduplicated verb as a response to an assessment in Finnish implies that the assessment is beyond doubt, and possibly something that has already been dealt with in prior conversation (Sorjonen and Hekulinen, 2009). It implies that there 
is no need to discuss the matter further and that the sequence may be brought to a close. Estonian reduplication, however, is used in a variety of sequential positions to achieve a number of specific social aims. In most cases, its function is not to bring the sequence to a close. Formally identical grammatical devices do not necessarily do interactionally identical work cross-linguistically. We will now look at the sequential positions and social achievements of reduplication in Estonian, while occasionally bringing in examples from other languages to show that at least some of the patterns are cross-linguistic.

\section{The data}

The data come from two corpora. The first one is collected and transcribed by myself and consists of 323 naturally occurring phone conversations (henceforth, the AU corpus). The conversations are by and large of two types: telemarketing calls from one of the biggest daily newspapers in Estonia (109 conversations), and everyday calls between family members, relatives, friends, and colleagues, recorded at informants' homes. There are more than 100,000 words in the AU corpus.

The other corpus is the publicly available Tartu corpus, which is constantly growing (henceforth, the TA corpus). At the moment, it consists of about 700,000 words, out of which more than 300,000 have been checked for relevant cases for this study. The data in the TA corpus come from a large variety of settings, including face-to-face conversations. Each example is provided with a code revealing its origin (AU, TA, respectively). Transcription and glossing conventions can be found at the end of the article.

\section{The phenomenon: reduplication, repetition or multiple saying}

Syntactic reduplication in this study involves an exact repetition of a word or a short word combination, which may constitute a turn on its own. It is said by a single speaker, while in some positions the word or word combination used is at the same time a repeat from the talk by a prior speaker. Several other conversational actions that encompass repetition, such as restarts and repetitions for somebody who did not hear, imply a new prosodic contour on the second item, even if the repetition itself may be verbatim. In contrast, reduplication is done in a single prosodic contour. It is produced and understood as doing a single action, not as redoing one. Prosodic coherence is one of the most important features of the practices analyzed in the current study. The reduplicated format is always produced by the same speaker without any pause or pitch reset (an abrupt jump higher or lower in the pitch register of the speaker) between the items. It displays a coherent prosodic contour, which is often characterized by a single stressed syllable. The contour may start either high or low, but it is never terminated after the first item. The first item projects another one to come, either by a non-terminal fall, by being too low and non-stressed to stand on its own, or by displaying a shorter second syllable that is immediately followed by the second item.

The practices described in the current study have to do with repetition of words and shorter word combinations. There are several different possibilities for categorizing and naming the phenomenon: syntactic reduplication, syntactic repetition, or multiple saying. Within linguistic research, reduplication means deliberate repetition of a sound sequence or a morpheme by the same speaker. When a whole word is repeated, such as adagio adagio 'slowly slowly' (Italian) or liten liten 'small small' (Swedish), the phenomenon is called syntactic reduplication (Wierzbicka, 1986:288; Lindström, J., 1999:14-41), because words are minimal independent syntactic units. In the current study, only repetition of whole words will be studied, which makes the term syntactic reduplication sound adequate. Besides, while reduplication generally allows for partial modification of the morphemes (Moravcsik, 1978:305-308), the words in this study are always repeated in identical morphological form. Characteristically, reduplication involves doubling of an item (Inkelas and Zoll, 2005), which is also the case in the current study. Some researchers even consider prosody an important factor in the definition of syntactic reduplication, demanding that the word would be repeated within the same prosodic unit (Israeli, 1997:588; Gil, 2005:44).

Problems with the term syntactic reduplication arise when more than one word is repeated. In the current Estonian data, there is no functional nor prosodic difference between, for example, repeating the positive form of 'to be' in 3rd person singular (on on), and repeating the negated form of the same verb (ei ole ei ole). The only difference is the fact that the negation happens to be expressed in a separate word and therefore the 
repeated unit is longer. Furthermore, reduplication also occurs with subject + verb combinations, such as in ma tean ma tean 'I know I know'. Again, there is no prosodic difference from lexicalized reduplicated items such as jaaja 'yeah yeah' or the reduplication of a multisyllabic word such as muidugi muidugi 'of course of course'.

As the difference between words and word combinations has been carefully maintained within linguistics, cases of repetition involving more than one word have been classified as syntactic repetition instead (Tannen, 1989:55; Erelt, 1997; Lindström, J., 1999:39-40). This term covers a wide variety of patterns involving repetition of sentences with various lengths as well as other-repetition. For example Jag är så ledsen så ledsen 'I am so sad so sad' (Swedish). Quite expectedly, nobody has claimed that syntactic repetition should be produced within a single intonation contour. Because of these two reasons, the category of syntactic reduplication still seems to provide a more adequate classification of the phenomenon.

In addition to the linguistic tradition, lately a new term, multiple saying, has been taken into use by Stivers (2004) within the conversation analytic framework. She outlines five features of a multiple saying, which

(a) involve a full unit of talk being said multiple times

(b) are said by the same speaker

(c) have a similar segmental character ${ }^{1}$

(d) happen immediately in succession

(e) are done under a single intonation contour (Stivers, 2004:261)

Comparing the list above with the terminology of the linguistic tradition, syntactic reduplication covers the factors $b-e$, and sometimes $a$ (as a single word can be 'a full unit of talk'), and syntactic repetition covers $a-d$. The advantage of the term multiple saying over reduplication is thus possibly the simultaneous occurrence of factors $a$ and $e$. Another difference is that reduplication involves repeating twice while multiple saying allows for a number of repetitions.

Stivers' (2004) examples of multiple sayings include items such as yes, no, right, wait, right there, wait a minute, I'll eat them. Similarly to the reduplication phenomena studied in this paper, no distinction is thus made according to the number of words involved in the repetition. However, Stivers' study relies heavily on particle repetition (yes, no, okay, alright, I see), while the current paper predominantly deals with repetition of verbs, nouns, and other representatives of major word classes. The functions of most practices described in the current paper are also markedly different from the halting of a larger course of action described by Stivers.

Therefore, and because of the long tradition of the term reduplication in linguistics, the practice will be called syntactic reduplication below, disregarding the one-word constraint maintained for syntactic reduplication in earlier studies. An additional reason for using the term is that the present study primarily relates to the research tradition of linguistics where grammatical patterns rather than types of social action are taken as a starting point for the analysis.

The paper focuses on syntactic reduplication of words and word combinations in sequential positions where they can potentially constitute a turn, which is the criterion for being considered a turn construction unit (first outlined in Sacks et al., 1974:702-703). It regularly occurs in a turn-initial position, followed by immediate speaker transition. Often the reduplicated item does indeed constitute an entire turn on its own. Thus, cases like oopis oopis teine 'completely completely different' will be left out since oopis oopis 'completely completely' is not on its own a turn construction unit.

Finally, even though numerous response particles ( $e i$ 'no', ja 'yeah', mhmh 'uhuh', muidugi 'of course') and reactive tokens ( $o i$ 'oh', ai 'too bad', jumal 'god') are used with the same formal characteristics of the reduplicative practice described below, they have been left aside. Their sequential positions and action import should be a topic of a separate study (for a somewhat different array of reduplicative syntactic patterns in Estonian, see Keevallik, 2001). In the following, we will concentrate on the types of social action implemented by reduplication of words other than

\footnotetext{
${ }^{1}$ Actually, the examples display not only similar but identical segmental character of the repeated units, apart from lengthening. Thus, in linguistic terms, it would be called total reduplication (e.g. Moravcsik, 1978:305).
} 
particles and reactive tokens. These include verbs ( on on 'is is'), nouns (ema ema 'mother mother'), adjectives ( $p \tilde{o n e v}$ põnev 'exciting exciting') and adverbs (kindlasti kindlasti 'for sure for sure').

The features of the reduplicative pattern studied here is thus the following. A case of syntactic reduplication

(a) involves a word or a short word combination

(b) is produced by one speaker

(c) displays doubling of a verb, noun, adjective, or adverb

(d) happens immediately in succession, without conjunctions

(e) is done in a single intonation contour

(f) constitutes a turn construction unit

In the following, the article outlines four different functions of syntactic reduplication discovered in the data. Syntactic reduplication, as defined above, is used to implement an urging or a challenge, to reinforce an answer to a yes/no question, or to assert rights to a claim produced by another speaker. Particular attention will be paid to pitch contours that are characteristic of each function and sometimes even instantiate contrasts in meaning.

\section{Imperative reduplication as responsive urging}

When used in responsive positions, imperative verb forms may be reduplicated in Estonian, constituting a specific responsive construction. Responsive constructions have been defined by Linell (2005a) as constructions where the linguistic form encodes that they cannot be the first contribution in the discursive sequence (episode). The patterns described below display their responsiveness partly by being reduplicated but primarily by implementing actions that are done in response to what went on in the just prior turn. Imperative forms of verbs, when doubled, regularly function as urgings in Estonian.

Urging here means that the speaker attends to a course of action reported by another speaker in a prior turn and either urges its continuation or the opposite course. In example (1), a grown-up daughter P has said that she will probably take a pumpkin from her mother's place at her next visit. Line 1 is the mother's positive response to this covert request. When the daughter describes the huge amount of pumpkin she consumes, the mother urges her to continue with that by using a reduplicated imperative in line 7 .

(1)

$1 \mathrm{E}: \quad$ [võta nii] palju kui tahad.=

take:IMP:2SG so many as want:2SG

Take as many as you want.

2 P: =ahah? te ei söö neid jah.= okay you NEG eat these:PRT yeah Okay. You don't eat them?

$3 \mathrm{E}: \quad=$ ei:.=

No.

$4 \mathrm{P}: \quad=\underline{\text { oi:: }}$ kui ea. [mul] läeb

OI how good I:ADS go:3SG

(That's) great. I use

$5 \mathrm{E}: \quad$ [jah,]

Yeah.

6 P: ühe nädalaga üks ära. one:GEN week:KOM one ÄRA one per week. 
$7 \mathrm{E}: \rightarrow$ sö0̈ $\quad$ söö.

eat:IMP:2SG eat:IMP:2SG

Go ahead and eat.

8 P: $\quad$ noo väga ea.=

NOO very good

Very good.

$9 \mathrm{E}: \quad=$ terviseks.

health:TRA

for your health.

$(\mathrm{AU})$

The mother here uses the reduplicated imperative as a response to the daughter's report. Its function is to display social affiliation with the daughter's reported pumpkin-eating habits and to encourage the behavior, all in the context of complying with the request that she be allowed to take the pumpkins from her mother's home.

However, the report does not make an urging relevant in the same way that a question makes an answer a relevant next action (e.g. Schegloff, 2007:13-14). An urging is merely one out of many possible reactions to a telling, such as neutral information receipts and general displays of surprise. By choosing to produce an urging, the speaker specifically affiliates with what has just been told to her. The urging formatted with imperatives furthermore displays the speaker's analysis of what she just heard. Rather than using a general receipt token, such as a 'yeah', this format requires a choice of a verb specific to the report. By producing sö̈ söö 'eat! eat!', the mother in the above example verbalizes her interpretation of lines 4 and 6, in which the daughter merely stated that she 'uses' one pumpkin per week. The reduplicated imperative urging is thus a volunteered next action to a telling that addresses the specifics of this telling in a way that many other alternatives do not. It therefore has interactional advantages, particularly by being heard as an affiliation. Accordingly, the daughter receives the urging with a positive assessment in line 8 .

In another case (example (2)), speaker L tells E that she has to continue babysitting a dog until the next day. The proadverb 'here' refers to where the dog lives and the pronoun 'his' refers to the dog's master. Speaker E reacts to the telling with a reduplicated imperative, affiliating with the report by L.

(2)

1 L: tomme õhtuni ma (XX) ilmselt olen tomorrow night:TER I probably be:1SG

I'll probably be here till tomorrow night,

2 veel $\underline{\text { siin, }}$ tal tuleb täitsa

still here he:ADS come:3SG quite

his plane lands

3 õhtu ilja see lennuk.

evening late this plane

quite late in the evening.

$4 \mathrm{E}: \rightarrow$ jaa ole ole,

yeah be:IMP:2SG be:IMP:2SG

Yeah, go ahead!

$5 \quad(0.5)$

$6 \mathrm{~L}$ [ [kolmapäval.]

Wednesday:ADS

On Wednesday.

$7 \mathrm{E}$ [ma elistan sulle jälle.]

I call:1SG you:ALL again

I'll call you again. 
In this case, the imperative format reuses the verb 'be' from L's turn (both of which are boldfaced in the example), which is an important feature of a number of reduplicated formats discussed below. This lexical repetition across speakers shows that the formats are indeed responsive and indexically tied to the prior turns.

The reduplicated imperative format is responsive, it cannot occur as the initial action in a sequence and it does not make any next action relevant. In contrast, the single imperative, e.g. 'eat!', often does make a compliance relevant. A non-reduplicated item thus entails a different action and it would be impossible to use it in this particular sequential position after a telling. This observation brings us back to the common assumption in reduplication studies that the reduplicated versions simply do more than the single items (Moravcsik, 1978:316). In the above two cases, the reduplicated imperative does something quite different from what the single imperative can accomplish. It is a particular format for doing urging and affiliation in a responsive position. Its function and sequential placement are different from that of single imperatives. It does not make relevant a compliance. Therefore, it is also problematic to claim that the repetition of the item "does not contribute to the meaning of the utterance" (Gil, 2005:44, on similar cases in Riau Indonesian). It certainly does, even to the extent that the implemented action becomes radically different.

In a somewhat divergent but equally frequent pattern, the reduplicated imperative format is used to disaffiliate from the report by a prior speaker. It still accomplishes an urging, but of a different kind. In excerpt (3), $\mathrm{E}$ and $\mathrm{K}$ are childhood friends who have not met for a long time. $\mathrm{E}$ has called $\mathrm{K}$ and in the upcoming segment of their conversation she tries to get $\mathrm{K}$ to draw some conclusion about her changed personality. $\mathrm{K}$ counters with laughter, another question and, facing reluctance by E, a reduplicated urging for $\mathrm{E}$ to speak up in line 15 .

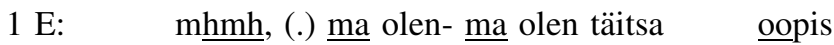

uhuh I am I am completely totally

Uhuh (.) I'm- I'm a completely

2 teistmoodi inimene präegu.

different person now

different person now.

$3 \mathrm{~K}: \quad$ oled $\quad$ jah,=

be:2SG QUES

You are?

$4 \mathrm{E}: \quad=$ jaa,

Yeah.

$5 \mathrm{~K}: \quad$ missugune sa oled s. what kind you are:2SG then

What are you like then?

6 E: mai tea. (.) [ma akkasin-]

I:NEG know I started:1SG

I don't know (.) I started

$7 \mathrm{~K}$ :

[teistmoodi.]

Different

$8 \mathrm{~K}: \quad \mathrm{ah}$ ?

What?

$9 \mathrm{E}: \quad$ ma õpin ju seal ee m Pedas

I study:1SG JU there NAME:INS

Well, I study choreography 
10 seda $\mathrm{m}$ koreograafiat. this:PRT choreography:PRT

at Peda.

$11 \mathrm{~K}: \quad$ no:h?

And?

$12 \mathrm{E}: \quad$ no:h, (0.6) sis mõtle ise peaga.

$\mathrm{NOH}$ then think:IMP yourself head:KOM

And. (0.6) So think yourself with your head.

13

(0.9)

$14 \mathrm{~K}: @ @ @ @$ @h @@@ hh mis m@is mõttes.

what what sense:INS

What- In what sense?

$15 \rightarrow \quad$ r@äägi räägi. @

tell:IMP:2SG tell:IMP:2SG

Tell (me)!

$16 \mathrm{E}: \quad \underline{\mathrm{ei}}$ räägi.

NEG tell

No, I won't.

17

$(0.5)$

18 K: @@ @ miks sa ei räägi. @ $>$

why you NEG tell

Why don't you tell?

$19 \mathrm{E}: \quad$ mkmm. (.) .h kule kas sa oled

no listen:IMP:2SG QUES you be:2SG

No. (.) .h Listen, do you

umbes samasugune vä. kui ma sind tänaval

about the same QUES if I you:PRT street:ADS

look about the same? If I met you on the

21

näeks s ma tunneks ära vä.
see:COND then I recognize:COND QUES
street, would I recognize you?

(AU)

In her pursuit to obtain an adequate guess from $\mathrm{K}, \mathrm{E}$ offers a hint for how she has changed during the years they have not met: she now studies choreography (which is already known to K, so it is brought in as an argument, not as new information, lines 9-10). Still, $\mathrm{K}$ only produces a go-ahead $n o: h$ after that, which $\mathrm{E}$ repeats in a dissatisfied manner. She then asks K to think himself, which leads to K's reduplicated urging for her to speak up. He seems to be treating E's behavior as mere shyness. (She most probably wants $\mathrm{K}$ to draw a conclusion on her physical appearance, possibly reduced body weight, which is an awkward fact for her to point out herself. $\mathrm{K}$ is male. This interpretation is supported by her lines 19-21 where E asks a counter-question about K's current appearance.) Even in this excerpt, the reduplicated pattern is used responsively towards the prior contribution by the other speaker. K reacts to E's resistance to answer his question about her changed personality and urges her to speak up against her just displayed unwillingness to do so. Her reaction to the urging is again a refusal. Thus, while being responsive to the prior refusal to speak, the reduplicated turn is simultaneously an initiative action, a request that gets turned down.

Another example on the insistence against the interlocutor's expressed will is given in (4). The speaker M explicitly says that she will not go to the sauna (line 5). Still, the speaker T repeatedly urges her to go with the reduplicated mine mine 'go! go!', to which $\mathrm{M}$ ultimately responds with a refusal. 
(4)

1 L: [Kule] Marili, (0.5) tule Tallinna ja

listen NAME come:IMP:2SG NAME:ILL and

Listen, Marili (0.5) come to Tallinn and

2 lähme Mardi juurde sauna.

go:1PL NAME:GEN to sauna:ILL

let's go to the sauna at Mart's place!

$3 \mathrm{M}: \quad<\mathrm{Q}$ präägu vä. $\mathrm{Q}>$

now QUES

Right now?

$4 \mathrm{~L}: \quad$ omme.

Tomorrow.

$5 \mathrm{M}: \quad$ hehe $<\mathrm{Q}[\mathrm{mi}] \mathrm{ne} \quad \underline{\text { ukksi, }}$ mina [ei lähe]. Q> go:IMP:2SG alone I NEG go

You go alone, I won't go.

$6 \mathrm{~L}:$

[äh]

[ mhmh ] ei:.

Uhuh, no

$7 \mathrm{~T}: \rightarrow \quad$ mine: $\quad$ Marili, mine mine. $^{2}$ (.)

go:IMP:2SG NAME go:IMP:2SG go:IMP:2SG

Go, Marili, do that!

$8 \mathrm{M}: \quad$ ei lä[he:,]

NEG go

No I won't.

$9 \mathrm{~T}: \rightarrow$ [mine] mine noh,

go:IMP:2SG go:IMP:2SG NOH

Do that!

$10 \mathrm{M}$ : ei lähe:

NEG go

No.

(TA)

The above two patterns of imperative reduplication both implement urging in response to a just prior action, but in different sequential positions, and their action import is not identical. In the first type (examples 1-2), what precedes is a telling or informing of some kind. In the second type (examples 3-4) the other participant has already displayed resistance toward the activity pursued, which can be characterized as exhortation or an intense proposal. In the first type, the urging affiliates with what the previous speaker reported, and in the second type, it explicitly disaffiliates with the prior speaker, urging her to do something that she has displayed resistance to. Finally, the response to the first type may even be a positive assessment, as happens in example (1), while in the second type, it is the re-instantiation of the already displayed resistance, at least in the examples (3) and (4) above. The second type is simultaneously an initiative action that makes relevant a response.

These two versions of a syntactically reduplicated imperative pattern are also deployed with markedly different prosodic patterns. The affiliating actions display the pitch peak at the beginning of the reduplicated construction, the disaffiliating action has the pitch peak later. The pitch contour in the affiliating action is either falling or relatively level, while in the disaffiliating action it may rise considerably. Also, the second item may be longer in the disaffiliating cases, while in the affiliating ones it is usually shorter. The pitch contours of the above examples are displayed below (contours 1-4).

${ }^{2}$ The verb 'go' is suppletive, so mine and ei lähe represent the same word. 

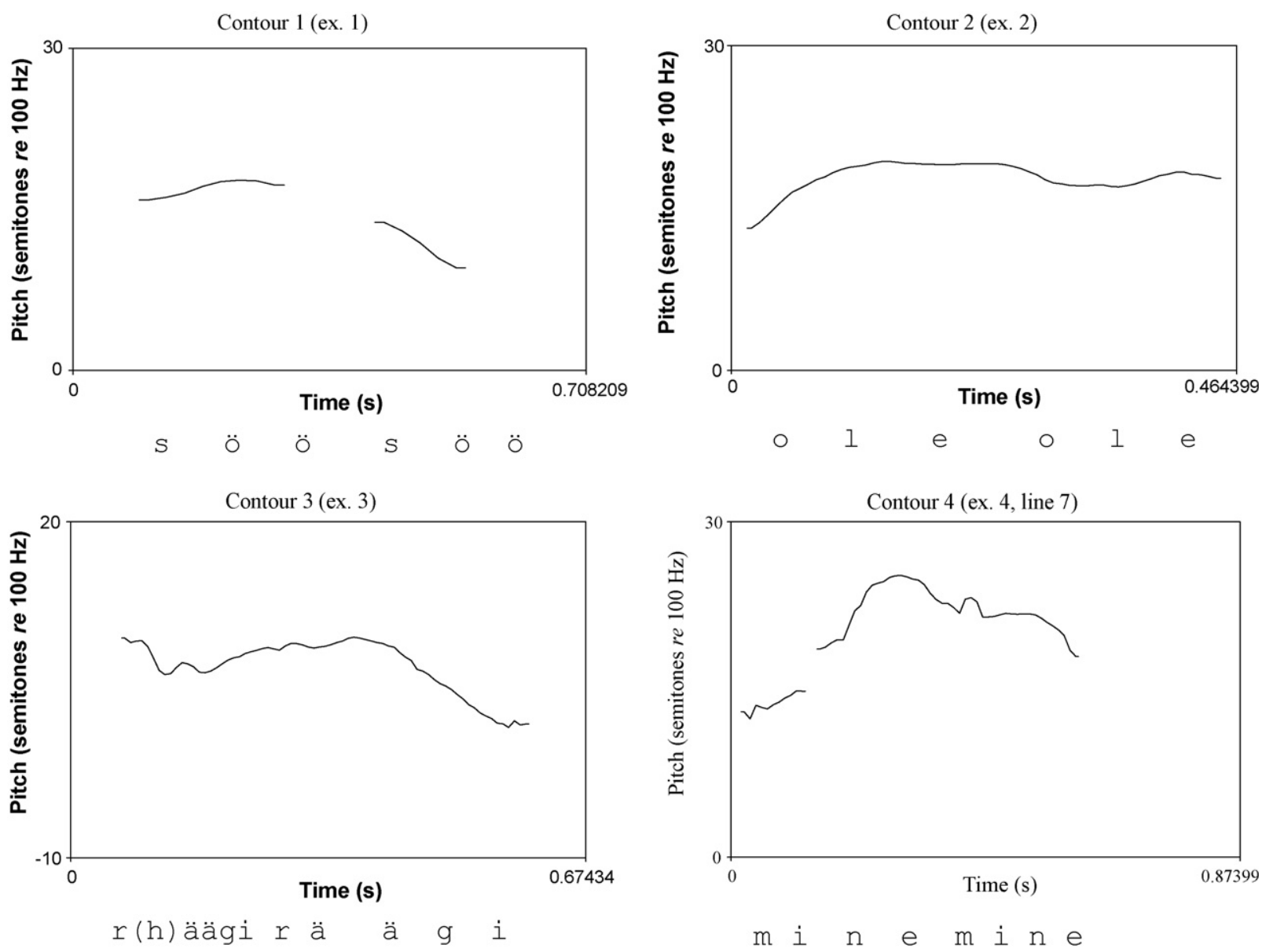

In the case of Estonian reduplicated imperatives, we can see that the prosodic pattern plays a crucial role in terms of which action gets done: when the interlocutor is encouraged to continue with whatever she has been talking about, the contour displays a high and stressed first item and a low and non-stressed second one. In contrast, when the interlocutor is urged to do something she is resisting, the second item in the reduplicative pattern is higher and more stressed.

A similar insisting practice with imperatives exists in Russian, as can be seen in the examples presented by Israeli (1997:599-600, examples 31, 32). In one of her excerpts, the interlocutor is urged to take the money he is apparently hesitant to accept. Two reduplicated turns are produced by the speaker who tries to give the money: deržite, deržite 'take! take!', lit. 'hold' and berite, berite 'take! take!'. The examples come from literary works, where no prosodic details can be found but the imperatives are obviously reduplicated for the purpose of insistence, similarly to the Estonian cases above.

It should also be pointed out that the practices described so far do not attempt to halt the wider course of action going on, as was described in the case of multiple sayings in the Stivers' study (2004). This is not necessarily surprising as identical grammatical means are often used on different purposes in different languages. However, there is one imperative in Estonian that is explicitly used to halt the ongoing action, namely oota 'wait!'. The item has shortened into ota, oot or ot and it can be extensively reduplicated, up to eight times, at least. It functions as a pragmatic particle halting the action, among other things in order to initiate an insert sequence or a topic change (Keevallik, 2003:126140). Its capacity of halting the action can be traced back to its original meaning of ordering the participants to wait and not that much to the reduplication per se, because the single item ot or ota can halt the action as well as the reduplicated ot ot ot ot (cf. Stivers' wait a minute, 2004:267). The prosodic patterns of these differ from those discussed above and because 'wait' has developed into a particle, i.e. it is not functioning as an imperative verb form in these cases, this falls beyond the scope of the present article. 
In Estonian, reduplicated imperatives are implemented to achieve two different kinds of responsive actions, urging the interlocutor to carry out some course of activities, either by affiliating or disaffiliating with what she herself has claimed. These two actions are characterized by contrasting prosodic patterns but they are both volunteered, not elicited, actions that display their responsive nature through their reduplicated form.

\section{Mock repeats as challenges}

Another reduplicated practice in Estonian is mock repeats, in which the speaker repeats a concept from a prior turn. Mock repeats constitute or preface a challenging turn, thus also constituting a responsive action. They involve primarily nouns and adjectives, but occasionally also adverbs and verbs. Let us consider the first example (5), which concerns a broken car seat. The speaker $\mathrm{K}$ in line 1 blames the mother for it, while another participant challenges this accusation by using a turn-initial mock repeat of the word 'mother'. The repeated items are boldfaced for easy reference.

$1 \mathrm{~K}$ : $\quad$ sste on nüüd puhta nässus.

seat is now completely broken

The seat is completely broken now.

2

3

ema lõhkus ka veel ära. mother destroyed:3SG also VEEL ÄRA

Mother destroyed (it) too.

$4 \mathrm{~T}: \rightarrow \quad<\mathrm{Q}$ ema ema. Q $>(($ osatab $))$

mother mother ((mock repeats))

What do you mean - mother?

5

$(0.8)$

6

ema sõitis ühe otsa ära mother drove:3SG one:GEN way:GEN $\ddot{\text { ÄRA }}$ Mother drove one way

midagi ei juhtund.

nothing:PRT NEG happen:PPT

and nothing happened.

There is a special term for this reduplicated pattern in Estonian (osatab) and the transcriber has used it to characterize the manner in which the turn in line 4 is produced. The existence of a term for a pragmatic pattern is itself a proof of its distinctiveness for the speakers. A mock repeat means that some concept is taken from the immediately prior turn and repeated in a reinforced manner to indicate trouble with the turn. Characteristically, also, the same concept is then repeated in the following explanation of the nature of the challenge. In this subsequent reference position, a pronoun should generally be used. The full noun is a marked form, which further underlines the relevance of this very concept for the challenging that the whole turn accomplishes. In example (5), according to T the blame has been directed to a wrong person and the repeated full reference underlines that.

Unfortunately, this kind of aggravated challenge is rare in the data, and examples are hard to find. In another case, in example (6), the concept referred to by a pronoun is then referred to by a name in the challenging turn. A mother (E) has called her daughter (M) to inquire whether she had been talking to Arvi at their mutual home as both M's work line and their home line had been busy at the same time. The pronoun $t a$ in line 2 refers to Arvi.

(6)

$1 \mathrm{E}: \quad$ ei no seda küll, ma mõtsin et no NO this:PRT KÜLL I thought:1SG that Well yeah, I thought he was still there 
ta on präegugi seal, ja teie omavahel

he is now:GI there and you:PL each other

and you two were talking to each other

3

räägite. [sellepärast (kuna)] mõlemad

talk:2PL therefore because both

because both

$4 \mathrm{M}: \quad[$.hh ei no- ]

No, wel-

$5 \mathrm{E}$ : numbrid olid juhtumisi [kinni]

numbers were by chance busy

numbers happened to be busy

$6 \mathrm{M}$ :

[jah,]

Yeah.

$7 \mathrm{E}$ : ü- ühel ja samal ajal.

one:ADS and same:ADS time:ADS

at the very same time.

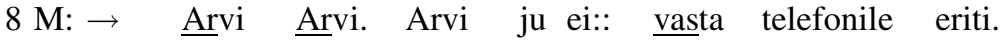

NAME NAME NAME JU NEG answer phone:ALL much

Arvi Arvi. (You know that) Arvi doesn't usually

answer the phone.

(AU)

At the beginning of this excerpt, the mother is giving an account for why she thought that her daughter and Arvi may have been talking to each other. Already during this account, $M$ attempts to initiate a disaffiliating turn of some sort in line 4. Also her jah 'yeah' in line 6 is produced with an impatient tone of voice. In line 8, M challenges E's whole reasoning by claiming that Arvi generally does not answer the phone. The challenge is initiated by the reduplicated Arvi and continued by a statement that also includes the full name. The particle $j u$ further down the turn expresses the assumption that the relevant information should be known to both current interlocutors, which further enhances the confrontational value of the turn.

The mock repeat has its own very distinctive prosodic pattern in Estonian. Most importantly, it involves two relatively heavy stresses. The intonation contours display a repetitive pattern, where the second item is marginally lower than the first one, if at all. Still, the construction is produced as one coherent whole with no indications of termination at the end of the first item. The contours of both examples are shown below (contours 5 and 6).

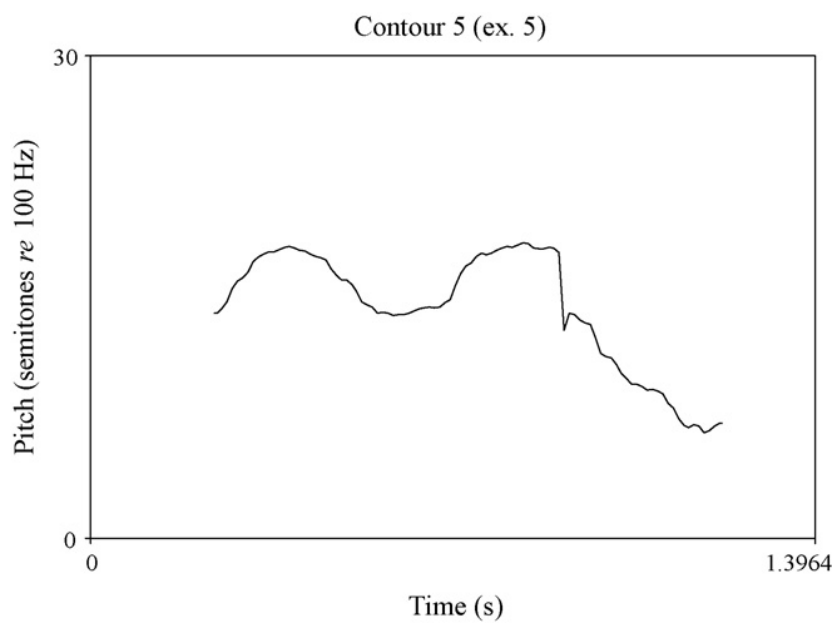




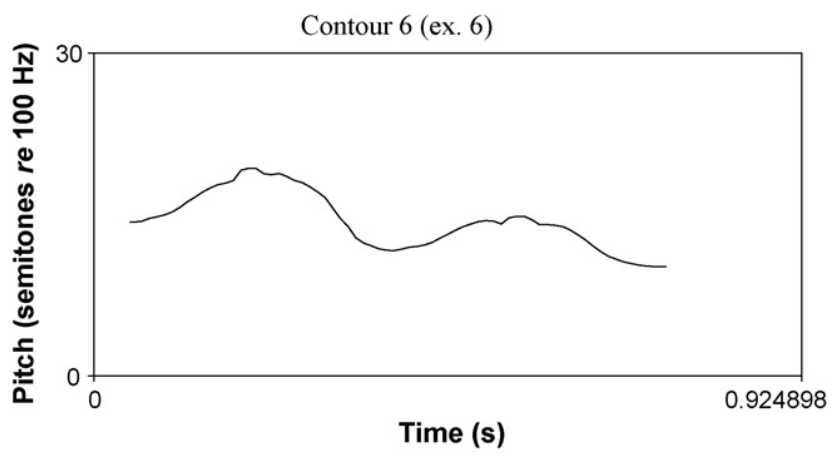

Similar, albeit literary, examples from Russian have been described by Israeli (1997:596-597), who points out that by reduplicating the repeated key word the speaker implies the irrelevance of the item in question. One of her examples is replicated in (7)

(7, Russian, adapted from Israeli, 1997:596)

1 A: Ran'še ty so mnoj tak ne razgovarival. earlier you with me thus NEG talked:MASC:3SG You didn't talk to me like this before.

$2 \mathrm{~B}: \rightarrow$

Ran'še, ran'še. Ran'še voobšče vse inače bylo.

earlier earlier earlier in general everything different was:NEU:3SG

So what? Everything was altogether different before.

However, the challenge is not quite about one item only. The speaker B in (7) is in fact not merely saying that the item 'earlier' is problematic but using it in order to challenge the relevance of the prior statement as a whole. Although the item that is repeated in both the above Estonian cases is a noun referring to a person, the challenge does not concern only the reference. It opposes some more general assumption that was conveyed in the prior turn, either explicitly, as with 'mother destroyed it', or implicitly by assuming that Arvi would have been talking on the phone. The reduplicated mock repeat is a disaffiliating action. It initiates a challenge but it does not yet necessarily display what exactly the nature of the problem is. It merely establishes a confronting stance toward what was just said and thereby ties the upcoming talk to the prior. Although a mock repeat is as a rule part of a multi-unit turn, it constitutes a separate turn construction unit. Turn-transition is possible after it but does not happen in the above cases and the speaker continues by explaining of the nature of the challenge. Crucially, again, a single item 'mother' or 'Arvi' in the same sequential position would be heard as implementing a different action, perhaps a repair initiation.

A functionally close repetition pattern occurs in Swedish. It is the so called X-and-X construction, where X stands for a word used by the prior speaker, and the repetition is done with a conjunction between the items (Lindström, J., 1999:230237; Linell, 2005a; Lindström and Linell, 2007; the latter source gives a number of other languages that use the X-and-X construction). This construction is similarly responsive and used turn-initially. It is obligatorily followed by a confirmation or foregrounding of some aspects of X's meaning, while it simultaneously cancels or backgrounds others.

(8, Swedish, from Lindström and Linell, 2007:32)

$1 \mathrm{~L}: \quad=$ du har (.) haft många inspelade samtal elleri

you have had many recorded conversations or

You have recorded many conversations, or?

$2 \mathrm{M}: \rightarrow$ ja-eh (.) många å många men de e nåra stycken så de-

yeah many and many but it is couple pieces so it-

Well (.) not really but there are some, so it-

However, the Swedish construction implements a milder disagreement. It is much less challenging than the mock repeat in Estonian and Russian, where some item or assumption is called into question and completely discarded in the 
following stretch of talk. Nevertheless, simultaneous repeating and doubling of a concept from prior talk seems to constitute a cross-linguistic device of challenging.

In summary, one way to use reduplication in Estonian is at the beginning of challenging turns, repeating a concept from a prior turn. The reduplicated item is followed by an explanation of the reason for the challenge. This is also valid for all the Russian examples provided by Israeli (1997:596-597), where the repeated key word is always followed by an explanation why the word is problematic, and the Swedish X-and-X construction (Lindström and Linell, 2007). Mock repeats are restricted to responsive turns, they cannot be implemented in initiating positions in an interactional sequence, and their structure displays orientation to preceding talk through repetition of some material from it. They are constituted with multiple means, involving grammatical reduplication, cross-speaker repetition, as well a specific prosodic pattern with strong prominence on both items.

\section{Reinforcing responses to yes/no questions}

In Estonian, yes/no questions can be answered either by a particle (the counterparts of 'yes' and 'no') or by repeating an item from the question, most often a verb (Keevallik, 2009). In addition, the repeated items can be reduplicated. A simple example from a telemarketing call is shown in (9), where the telemarketer inquires about a preliminary subscription. The pitch track of the turn is shown as contour (7).

(9)

$1 \mathrm{M}: \quad=m t s$. öelge palun, kas see:

tell:IMP:2PL please QUES this

Tell me please, (about) the preliminary

$2 \quad$ kahekümnepäevane tutvumistellimus Liivi

twenty-day preliminary subscription NAME

twenty-day subscription to Liivi

3 Linnalehele. kas leht käib teil.

NAME:ALL QUES paper goes you:PL:ADS

Linnaleht, do you get the paper?

$4 \mathrm{~K}: \rightarrow \quad$ käib käib,=

goes goes

Yeah.

$(\mathrm{AU})$

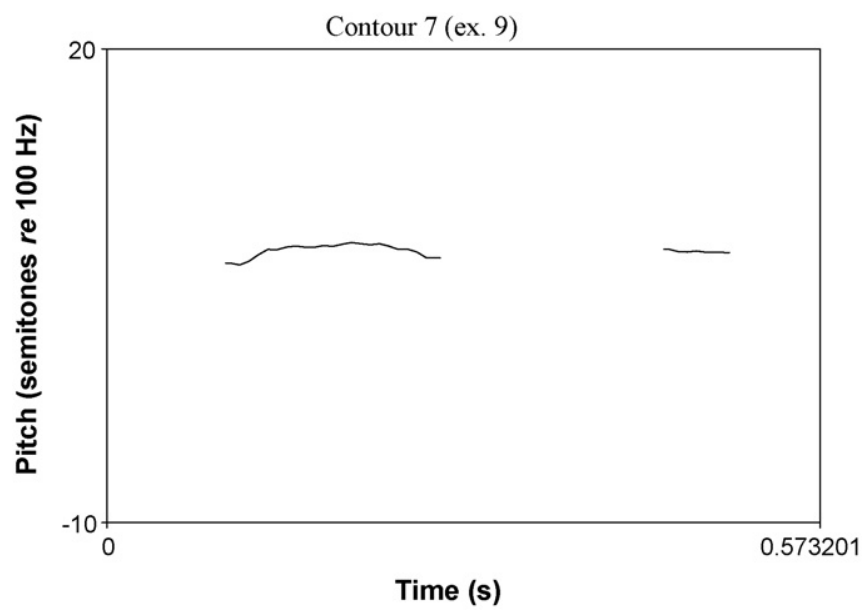

The answer basically provides a confirming response to the yes/no question. Although the verb is reduplicated, the construction is produced as a single whole, i.e. the second item is not done as a new version of the answer. There is no cutoff or final lengthening on the first item, no pitch reset at the beginning of the second item and no pause 
between the two. A reduplicated response is one possible, if relatively rare answer format to a yes/no question (for example, in a corpus of about 600 positive answers to positive questions there were 262 particle answers, 30 verb repeats and 5 reduplicated responses (Keevallik, 2009)). It can also be used in the negative form. In example (10) a negatively formulated question gets a confirming negative reduplicated answer. It comes from the beginning of a telephone call.

$1 \mathrm{M}: \quad . h \ddot{a ̈}$ tere Merilin on siin.

hi NAME is here

$\mathrm{Hi}$, this is Merilin.

$2 \mathrm{~V}: \quad$ tere,

Hi!

$3 \mathrm{M}$ : @ ega Kadrit vist ei ole.

EGA NAME:PRT probably NEG be

Kadri isn't there, I guess.

$4 \mathrm{~V}: \rightarrow$ ei ole ei [ole.]

NEG be NEG be

No, (she) isn't.

$5 \mathrm{M}: \quad[\mathrm{mhmh}]$

Uhuh

$(\mathrm{AU})$

In these two examples (9-10), the polarity of the answers matches the polarity of the questions. A positively formulated yes/no question receives a confirming answer and so does the negatively formulated one. In contrast, formally similar reduplicated answers to yes/no questions in the closely related Finnish language regularly reverse the polarity of the question (Hakulinen et al., 2004:1148). These answers go against the polarity expected in the question. In example (11), a negative question receives a reduplicated positive response.

(11, Finnish, simplified example from Hakulinen et al., 2004:1148)

$1 \mathrm{M}$ : eiks sulla jạää siihen numeroo.

EIKS you:ALL remain:3SG there:ILL number

Didn't you have the number there?

$2 \mathrm{E}: \rightarrow$ jạä $\quad$ jää.

remain:3SG remain:3SG

I do.

Reversing the polarity of the yes/no question with a reduplicated answer is a possibility also in Estonian, it is just not a regular characteristic of these answers. A reversed-polarity answer occurs in excerpt (12). The daughter $\mathrm{P}$ has taken along a CD from her mother's place but has only just told her about it on the telephone. In line 1, the mother E asks whether she took more CDs than the one she just mentioned.

1 E: [ro]hkem sa ei võtnud ve.

more you NEG take:PPT QUES

You didn't take anything else?

2 P: ei rohkem mai võtnud. ks sa

no more I:NEG take:PPT QUES you

No, I didn't. Do you

3 tunned tast puudust. ma toon

feel:2SG it:ELT lack:PRT I bring:1SG

miss it? In that case I'll bring 
ta kohe tagasi [sis].

it immediately back then

it right back.

$5 \mathrm{E}: \rightarrow$

\section{[ei tu]nne ei tunne.= \\ NEG feel NEG feel \\ No, I don't.}

5 P: =aa, =

$\mathrm{Oh}$.

$6 \mathrm{E}: \quad=k u u[l a \quad$ oolega. $]$

listen:IMP:2SG much

Listen as much as you want.

(AU)

The yes/no question in lines 1-2 puts forward an assumption that the mother may miss her CD and the turn is continued by an offer to bring it back. All this formally projects an answer with positive polarity. Mother's negative reduplicated response goes against this projection. However, socially the response is dealing with a more complicated situation. The daughter has made a (delayed) request to borrow the $\mathrm{CD}$ and is now offering to bring it back, after the mother has told that she really likes it too. Besides, the mother has not yet explicitly said that the request is granted. Furthermore, she has just insinuated in line 1 that the daughter may have taken more CDs than she reported (which is potentially heard as an insinuation as well). Thus, after the daughter's offer to bring the CD back, the mother has to deal with all these contingencies. Her answer to the yes/no question is indeed stronger than a mere disconfirmation. First, she reduplicates the negative answer, and second, she finally grants the request by the encouraging 'listen as much as you want'.

In examples like this, it appears that the reduplicated response constitutes a stronger answer than a single verb repeat. A simple particle 'no' or a verb-repeat answer in the negated form, which are technically also options in this position, would not have provided the adequate disconfirmatory strength, which is necessary to respond to the several contingencies hanging in the air. By reduplicating the disconfirming answer, the mother increases its strength. The capacity of reduplication to increase the strength has been pointed out in numerous semantically oriented studies (Moravcsik, 1978:317; Abbi, 1980; Botha, 1988:97, 115-117; Erelt, 1997 among others). However, there is also some interactional evidence that the reduplicated responses are more definitive than the single ones in the sense that they implicate closure of the question/answer sequence. When an answer to a yes/no question is reissued for some reason, the consecutive version may be carried out with a reduplicated item. In example (13), the telemarketer launches a question about whether the address the client has given is in fact sufficient. In line 5, he asks for a reconfirmation of the client's confirmatory answer.

$1 \mathrm{M}: \quad=$ =aga ku ma panen lihtsalt Kullamaa sidejaoskond, but if I put:1SG simply NAME post office

But if I put simply Kullamaa post office,

2

[kas] tuleb kohale ilusti.=

QUES comes place:ALL nicely

will it arrive safely?

$3 \mathrm{~K}: \quad[\mathrm{mhmh}$,

Uhuh

$4 \mathrm{~K}: \quad=$ jah,

Yeah

$5 \mathrm{M}: \quad \underline{\text { tu}}[\mathrm{leb}$ jah]?

comes QUES

Will it?

$6 \mathrm{~K}: \quad[\mathrm{jah}$,

Yeah 
$7 \mathrm{~K}: \rightarrow$ tuleb [tuleb.]

comes comes

It will.

$8 \mathrm{M}: \quad[$ no $\quad$ se $] l g e . /---/$

NO clear

Fine.

The telemarketer's original question receives a minimal confirmatory response already in line 3 . It is then upgraded to a 'yeah' in line 4, when the question has been terminated. During the subsequent checking question by the telemarketer, the client once again responds with the confirmative particle, and only after that she finally uses the reduplicated item, which in this position can be analyzed as an upgrade from 'uhuh' to 'yeah' to the reduplicated verb repeat. The reduplicated answer indeed ultimately terminates the sequence, as in line 8 the telemarketer finally acknowledges the answer. The reduplication renders the answer the necessary confirmatory strength.

Evidence of the usage of reduplicated verbs in similar sequential context for the purpose of an upgrade comes from a genetically very different language, Japanese. In the following excerpt (14), Kumi has just started to video record her guests and in line (1) one of them asks whether gesture would also constitute the data for Kumi's study.

$(14, \text { Japanese })^{3}$

1 Mari: $\quad$ Doosa demo naru?

gesture even become

Even gesture (will) be (data)?

2

(.)

3 Kumi:

$[\mathbf{N}(\mathrm{h}) \operatorname{ar}(\mathrm{h}) \mathbf{u}$ yo.

become YO

(It) will.

4 Mari: $\quad$ [Doosa wa?

gesture TOP

How about gesture?

5 Kumi: $\rightarrow \quad$ Naru naru

become become

(It) will.

Similarly to the Estonian pattern, the question is first answered affirmatively in line 3. After a confirmation request, the verb is reduplicated. In both Estonian and Japanese, the subsequent instantiation of the confirmation is a reduplicated verb repeat, showing that reduplicated responses are indeed stronger answers and have the capacity to bring a longer questioning sequence to a close. However, while implying closure-relevance for the sequence (i.e. not projecting any continuation beyond themselves, Schegloff, 2007:117), reduplicated answers still provide the sequentially relevant action of responding to a yes/no question. They do not interfere with the developing sequence. By being strong (dis)confirmations, they merely imply that the matter has been sufficiently dealt with.

When it comes to prosody, many of the answers are overlapped and do not provide for clear pitch traces. However, there is a distinction between the confirming and disconfirming answers. The confirming answers display a falling intonation all the way and prominence on the first syllable, with the second item much less prominent and reduced. In contrast, disconfirming answers, such as the one in (12) have prominences on both items, as shown with the underlining in the transcription. In another relevant excerpt (15), the pitch contour may be drawn in its entirety. This spate of talk comes from a telemarketing call, where the telemarketer has got the wrong number. The question in line 1 is her attempt to find out whether she has by mistake dialed the number of another person on her list. This question has a positive polarity. After a pause, she produces a very short and low $e i$ 'no' as if to herself, and almost in overlap the client answers negatively with a

\footnotetext{
${ }^{3}$ The author is indebted to Satomi Kuroshima for this example.
} 
reduplicated response. In this example, the connotation that the telemarketer's testing of different names should be terminated, is imminent, as the client goes on to suggest a new course of action for her, 'dial again!'.

$1 \mathrm{M}: \quad$ teie olete $\quad$ Allik vä.

you be:2PL NAME QUES

Are you Allik?

2

$3 \mathrm{M}: \quad$ ei.= $($ (to herself $))$

No.

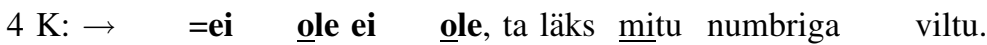

NEG be NEG be it went many number:KOM wrong

No (I')m not. It went wrong with several numbers.

valige veel uuesti.

dial:IMP:2PL more again

Dial again!

(AU)

This reduplicated response is produced with two equal stresses and equal pitch height on both items, as shown in contour (8).

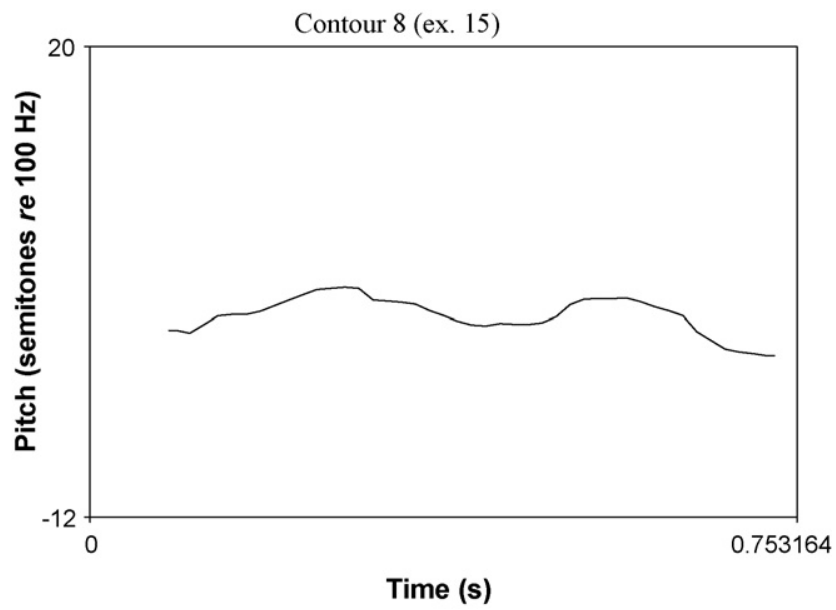

There is thus a prosodic difference between verb-repeat responses that match the polarity of the yes/no question and those that do not. Matching responses tend to be level or falling from first item to the second and display one stress, while non-matching ones have two stresses and two pitch peaks. The over-arching regularity of these prosodic patterns in interaction thereby starts to emerge, where affiliating actions such as encouraging and answering with matched polarity is done with different contours (prominent first item, falling) as compared to mock repetitions, urging against the will of other, and reversed polarity answers (second item also prominent). ${ }^{4}$

\footnotetext{
${ }^{4}$ The prosodic picture gets more complex when repeats of other word classes besides verbs are considered. Answers repeating nouns or adjectives display more varied prosodic patterns, which may reflect upon the fact that only confirmations can be carried out by them, and there is thus no potential contrastive meaning available for the reduplicated pattern.

$1 \mathrm{E}: \quad$ ahah .hh nad on sul see tähendab kodus.

AHAH they are you:ADS it means home:INS

$\mathrm{Oh}$, it means that they are at your place.

$2 \mathrm{~A}: \rightarrow$ kodus ko[dus].

home:INS home:INS

Yeah, they are. 
Reduplication of the (verb-)repeat is one format among many to answer a yes/no question in Estonian. Other unmodified options include particle answers, (verb-)repeat answers and combinations of those. All of them provide a confirmation or a disconfirmation, but at the same time reflect on matters of sequential positioning, action import, and epistemic features of the question (Keevallik, 2009). Several studies on English have shown that even when producing actions in the relatively constrained sequential position after questions, speakers attend to various social and interactional matters in their answers. They may, for example, imply that the question design was somewhat flawed (Raymond, 2003), or downright apposite (Heritage, 2002). They may deal with aspects of how the respondent is positioned with respect to the questioner (Heritage, 1998; Schegloff, 1996a). Repeat answers in Estonian are in general more independent affirmations than particles, as they contain a whole proposition and are thus less dependent on prior turns in terms of their content. When the answer reverses the polarity, particles cannot even be used as answers, making verb repeat the only option (Keevallik, 2009:41-43). When verb repeats are furthermore reduplicated, they seem to imply closure-relevance for the sequence.

In short, reduplicated answers are "stronger" and reinforced, which is what has been maintained in numerous earlier studies on reduplication. Reduplicated items have been said to express something more than their nonreduplicated counterparts, such as longer duration, intensification, more of a property, etc. More form is in correlation with more meaning, or even more specific meaning (Moravcsik, 1978:330). In the case of answers to yes/no questions, this line of reasoning seems to be valid. However, what they do more, is in the realm of interactional needs and projects of the participants. They treat the prior question as being in need of a reinforced answer, be it on the grounds of providing an emphatic affiliation (example (10)), reversing an undesirable understanding by the prior speaker (example (12)), terminating the confirming sequence (example (13)) or the ongoing course of actions (example (15)). Reduplication is used to design answers in a socially sensitive way.

\section{Asserting rights for other's claim}

The last reduplicative pattern that emerges in the data is an affirmation of a prior turn that amounts to indicating that the current speaker is indeed the one who has the rights to provide the information in it. While interacting, speakers manage not just where the sequence is going, and who knows what but who has rights to know about what. This is central for the participants in managing both their reputation, and thus their territories, and their relationships with one another (Stivers, 2005:155). Stivers (2005) has shown that one way of claiming epistemic rights to a topic, particularly an assessment, is to repeat part of it with regular modifications in the next turn. Furthermore, Finnish reduplicated responses to assessments have been said to claim independent access to the information (Sorjonen and Hekulinen, 2009). The reduplicated Finnish on on, lit. 'is is' shows among other things that the prior assessment is too self-evident for the current discussion. The Estonian reduplicative pattern occurs not only after assessments but after statements of various character.

In excerpt (16), L tells about an older acquaintance who has missed the deadline for social benefits application. This story could be received with any number of neutral acknowledgements. However, the recipient of the story volunteers a reduplicated confirmation to the acquaintance's claim that a retroactive application for benefits is impossible.

1 L: /- - -/ saadeti paberid kodu kõik ja sent:IMF:IMS papers home:ILL all and The papers were sent to her and

2 tema ee vaadand et ah ei ole tänavaasta she look:PPT that AH NEG be this year she had looked that this year

3 vaja midagi (.) järgmine aasta. hehe (2.0) need nothing:PRT next year nothing has to be done. (.) Next year. (2.0)

4 ja ma ütsin kas nüüd tagantjärgi ei $\underline{\text { saa }}$ and I said:1SG QUES now afterwards NEG can I said, can't (you) do it in retrospect 
üts et enam ei $\underline{\text { saa. }}$.

said:3SG that any more NEG can

(She) said, it can't be done any more.
$6 \mathrm{~A}: \rightarrow$ ei $\quad$ saa ei $\quad \underline{\text { saa. }}$ ((teadvalt))
NEG can NEG can ((knowingly))

No, (it) can't.

The confirmation in line 6 is not elicited. It thereby differs crucially from the above adjacency pairs where the first pair part made the second pair part relevant. Confirmations in positions where they are not elicited manage interpersonal relations (Stivers, 2005). For example, modified repeats are a way of doing confirmation that, through the redoing of a just prior claim, undermines the prior speaker's right to make the claim in the first hand. Instead, it asserts the second speaker as having primary rights to make the claim and manifests his or her own epistemic authority over the matter (Stivers, 2005:153). This is exactly what happens in example (16) above, where the confirmation involves a repeated verb from the prior turn by another speaker. The reduplication of the verb in the answer displays similar redundancy to the responses studied by Stivers. It seems to be designed to claim independent rights on the topic. More form is in this case iconically connected to the authority claimed by the speaker.

Crucially, though, a single verb cannot carry out the same type of action. A repeat of a single verb cannot be used to volunteer a confirmation in this position. Instead, it would most probably be heard as a repair initiation. Thus, the reduplicated answer format is not doing more of what the single format would, but a different social action. Reduplication thus creates a contrast in the linguistic sign system, much as it does when marking plural in contrast to singular, and repeated or continued occurrence in contrast to single terminated one (Moravcsik, 1978:317-321). Simply, the contrast in the cases studied here concerns types of action.

In another sequence involving non-elicited confirmation (example 17), the interactants are discussing the cast for a Christmas show. The director $E$ is explaining the way it has worked so far. A makes a judgement over the state of affairs in lines $4-5$, which is confirmed by $\mathrm{E}$ in a reduplicated format.

1 E: $\quad=$ ja siis oligi nii et, .hh Viljar, (0.4) sina and then was:GI so that NAME you And then it was like: Viljar (0.4) you'll

oled see. @ ja siis .hhh [Kaupo on kirjutaja]. be:2SG this and then NAME is writer be this and Kaupo will be the writer

3 A:

[ei no siis see saab] no NO then it can:3SG

Well, then it's okay.

4

ma arvan küll et seda on võimalik I think:1SG KÜLL that this:PRT is possible I think it's possible

niimodi sättida.

in this way arrange:INF

to arrange it like that.

$6 \mathrm{E}: \rightarrow$ no on on, ega ei jää muud üle ka.

NO is is EGA NEG be else:PRT left either

It is. There is no alternative.

In this conversation, $\mathrm{E}$ is the expert on the cast solutions for the show. When A states her opinion on the manageability of the situation, E reclaims her rights to making that statement by repeating and reduplicating the verb used by A. By choosing the reduplicated format and not a shorter alternative, a particle or a single verb, the speaker is 
Table 1

Social actions and prosodic prominences of reduplicative constructions.

\begin{tabular}{llll}
\hline & Prominence on 1st item & Prominence on 2nd item & Contour no. \\
\hline Affiliative urging & $\mathrm{X}$ & & 1,2 \\
Disaffiliative urging & & $\mathrm{X}$ & 3,4 \\
Mock repeat & $\mathrm{X}$ & $\mathrm{X}$ & 5,6 \\
Same polarity answer & $\mathrm{X}$ & $\mathrm{X}$ & 7 \\
Reverse polarity answer & $\mathrm{X}$ & $\mathrm{X}$ & 8 \\
Asserting rights & & 9 \\
\hline
\end{tabular}

doing more than merely confirming E's statement. By repeating the verb from the prior turn, she is making a more independent claim on the issue, as the verb conveys more information than a particle would and thereby constitutes a more independent statement. By reinforcing the answer with reduplication, the speaker shows that it was in fact her right to make this claim. This is a pattern that emerges across several examples.

Volunteered confirmations that (re)establish speaker's rights to the statement also display special prosodic features. The prosodic contour of the reduplicated turn in (17) has the highest pitch peak and heaviest stress in the second item, as shown in contour (9)..$^{5}$ The recording of (16) is unavailable but the transcript suggests an identical pattern.

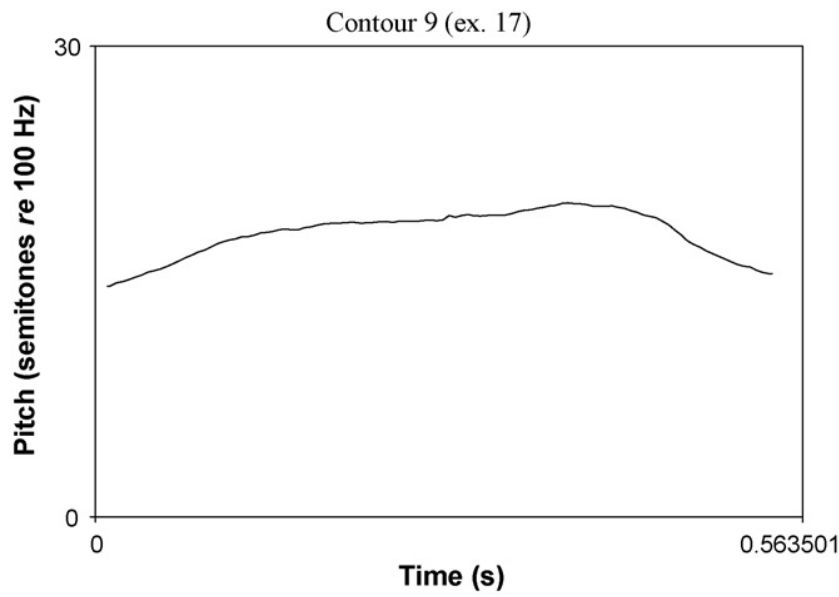

The delayed pitch peak was also characteristic of disaffiliative urgings. This falls into the general emerging prosodic picture, where actions that are most affiliating only have prominence on the first item, while the disaffiliating ones have a prominent second item or the pitch peak is delayed (as in contour 4). When the peak is on the first item, the contour may be falling (contour 1) or level (contours 2,7). Mock repeats and disconfirming answers to yes/no questions display two prominences. The summary is presented in Table 1.

The contours displayed above show that there is no straightforward connection between the social/sequential function of the reduplicative construction and their prosodic contours. However, each pattern described above also entertains a characteristic prosodic pattern. Prosody lives in a sequential environment. It contributes to the interactional projects of the speakers, occasionally also marking contrasting social meanings, where actions are otherwise achieved by the use of an identical grammatical device.

\footnotetext{
5 This regularity corresponds to the findings in German conversation, where two different variants of the reduplicated response token jaja display a very similar prosodic contrast (Golato and Fagyal, 2008). When jaja has its pitch peak on the first syllable, it simply shows that additional information is unnecessary. In contrast, when the pitch peak is on the second syllable, it implies that the speaker has more information than the other interlocutor. It is not possible to discuss the Estonian reduplicated particle jaja within the confines of the current paper but it actually occurs with the same prosodic parameters and pragmatic contrast as the German jaja.
} 


\section{Conclusion}

Instead of starting with the semantic features of intensity or emphasis, which have been claimed to be the functions of reduplication in a number of linguistic studies, this paper focused on social action. It revealed that in contrast to single items, reduplicated constructions may achieve quite different aims. It is impossible to accomplish a non-elicited confirmation by only repeating the verb from prior turn once. A single imperative is not usable as an encouragement in the above sequences and instead of a challenge, repeating a single item from prior turn functions as a repair initiation. In the case of yes/no questions, the reduplicated form achieves a stronger answer which implies sequence closure. Reduplication thus constitutes an important functional contrast with single items. Even though in some cases they are usable in identical sequential positions, their meaning and action import are different.

In terms of social action, reduplicated constructions asserted speaker's topical rights, instantiated a strong closureimplicative answer and encouraged or challenged a prior speaker. This adds an important facet to prior studies on reduplication, as it shows that the iconic potential of a reduplicated construction can only be realized in certain positions in conversation. Grammar is thus realized locally, within the contingencies of particular matters rising from prior talk and it is questionable to what extent it makes sense to characterize grammatical devices with abstract semantic concepts, such as "increase" or "intensification". The use of grammar is dependent on interactional matters, action sequencing, and achievement of specific social aims. It is adapted to the sequential nature of human conversation (Schegloff, 1996b; Linell, 2005b). Syntactic reduplication is a sedimented linguistic pattern grounded in the social actions it recurrently performs, such as confirming, affiliating or disaffiliative urging, challenging with mock repeats and asserting topical rights. Many usages in Estonian have counterparts in other languages, such as Finnish, Russian, Swedish, and Japanese. The grammatical phenomenon of reduplication is crucially intertwined with socialinteractional matters.

Reduplication is a piece of responsive grammar, used for reacting to a just prior turn. Reduplicated imperatives urge the prior speaker to do something he/she just talked about, reduplicative constructions are used to answer a question by another speaker, to challenge what was just said by another speaker, or to assert one's rights to what was claimed by somebody else. Most types of action furthermore implied repeating the word or concept initially produced by another participant. All answers to yes/no questions, mock repetitions, assertions of rights, and some urgings with imperatives employ repetition across speakers. Answers with reversed polarity are regularly done with the same verbs but in the opposite polarity. Reduplicative syntactic practices are thus responsive by their nature even when it comes to the lexical matter used.

In addition, different actions display characteristic prosodic patterns that constitute integral parts of the practices of talking. The analysis above showed that the contrast between affiliating and disaffiliative urging was marked by a prosodic contrast with the prominence either on the first or the second item in the reduplicated construction. Mock repeats and reverse polarity answers both displayed two prominences instead of one. Grammar and prosody interlace when it comes to constituting action and separating out one or another significantly reduces our possibilities to understand how language works. The grammatical phenomenon of reduplication needs to be treated with regard to prosodic as well as social-interactional matters.

\section{Acknowledgements}

A version of this paper was presented as a LISO-talk at UCSB and the author is grateful for the insightful discussion there, particularly to Sandra Thompson for the individual consultation. Many helpful points were made by Emanuel Schegloff and the Soc $289 \mathrm{~b}$ class at UCLA on these and related reduplicative phenomena. Thanks to Eva Liina Asu for great remarks on prosody.

\section{Appendix A. Transcription conventions}

$\begin{array}{ll}\text { underlining } & - \text { stress or emphasis } \\ \text { bold } & - \text { the repeated lexical item in focus } \\ - & - \text { truncation } \\ {[]} & - \text { overlaps } \\ = & - \text { latching }\end{array}$


$(0.5)$

(.) colo:n

@

(h)

$<$ Q quality Q $>$

$<@$ smiling@ $>$

.hh

mts

(X)

$?$

i

,

((snort))

/- - - /

(added)
- pause length in tenths of a second

- micropause

- lengthening of a sound

- a laughter syllable

- laughter within a word

- special quality of talk

- smiling voice

- breathing in, the estimated relative length corresponds to the number of h-s

- lip smack

- talk cannot be heard, X corresponds to one syllable

- pitch fall at the end of an intonation unit

- pitch rise at the end of an intonation unit

- half-rise at the end of an intonation unit

- level pitch at the end of an intonation unit

- unfinished intonation unit

- transcriber's comments

- something has been left out from the same turn in the example

- this part added in idiomatic English

\section{Appendix B. Glossing conventions}

\section{$1,2,3$}

ADS

ALL

COND

ELT

GEN

GI

ILL

IMF

IMP

IMS

INF

INS

KOM

MASC

NEG

NEU

PRT

PL

PPT

TOP

QUES

SG

TER

TRA

other capital letters
- person

- adessive

- allative

- conditional

- elative

- genitive

- emphatic suffix

- illative

- imperfect

- imperative

- impersonal

- infinitive

- inessive

- komitative

- masculine

- negation particle

- neuter

- partitive

- plural

- past participle

- topicalizer

- question particle

- singular

- terminative

- translative

- untranslateable particles

\section{References}

Abbi, Anvita, 1980. Semantic Grammar of Hindi. A Study in Reduplication. Barhi Publications Private Ltd, Chandigarh.

Botha, Rudolph P., 1988. Form and Meaning in Word Formation. A Study of Afrikaans Reduplication. Cambridge Studies in Linguistics.

Supplementary volume. Cambridge University Press, Cambridge. 
Brown, Penelope, Levinson, Steven P., 1987. Politeness: Some Universals of Language Usage. Cambridge University Press, Cambridge.

Couper-Kuhlen, Elizabeth, Ford, Cecilia E. (Eds.), 2004. Sound Patterns in Interaction: Cross-Linguistic Studies from Conversation. John Benjamins, Amsterdam/Philadelphia.

Couper-Kuhlen, Elizabeth, Selting, Margret (Eds.), 1996. Prosody in Conversation: Interactional Studies. Cambridge University Press, Cambridge.

Couper-Kuhlen, Elizabeth, Thompson, Sandra, 2008. On assessing situations and events in conversation: 'Extraposition' and its relatives. Discourse Studies 10 (4), 443-467.

Erelt, Mati, 1997. Reduplication in Estonian. In: Erelt, M. (Ed.), Estonian: Typological Studies II. Tartu Ülikooli Eesti keele õppetooli toimetised 8. Tartu, pp. 9-41.

Erelt, Mati, 2008. Intensifying reduplication in Estonian. Linguistica Uralica 44 (4), 268-277.

Erelt, Mati, Punttila, Matti, 1992. Reduplikatiivsed võrdlustarindid absoluutse superlatiivi väljendusvahendina eesti ja soome keeles. Lähivertailuja 6. Kielitieteellisiä tutkimuksia 27. Joensuu, pp. 7-23.

Erelt, Mati, Punttila, Matti, 1993. Lausesisesest tõhustusreduplikatsioonist eesti ja soome keeles. In: Yli-Vakkuri, V. (Ed.), Studia Comparativa Linguarum Orbis Mare Baltici. 1. Tutkimuksia syntaksin ja pragmasyntaksin alalta. Turun yliopiston suomalaisen ja yleisen kielitieteen laitoksen julkaisuja 43. Turku, pp. 159-172.

Erelt, Mati, Punttila, Matti, 1999. Suomalais-ugrilaisten kielten reduplikaatiosta. Lähivertailuja 10. Folia fennistica \& linguistica 23. Tampere, pp. $3-12$.

Ford, Cecilia E., 1993. Grammar in Interaction: Adverbial Clauses in American English Conversations. Cambridge University Press, Cambridge.

Fox, Barbara, Thompson, Sandra A., 1990. A discourse explanation of relative clauses in English conversation. Language 66 (2), $297-316$.

Gil, David, 2005. From repetition to reduplication in Riau Indonesian. In: Hurch, B. (Ed.), Studies on Reduplication. Mouton de Gruyter, Berlin, pp. $31-64$.

Golato, Andrea, Fagyal, Zsuzsanna, 2008. Comparing single and double sayings of the German response token ja and the role of prosody: a conversation analytic perspective. Research on Language and Social Interaction 41 (3), 241-270.

Goodwin, Charles, 1979. The interactive construction of a sentence in natural conversation. In: Psathas, G. (Ed.), Everyday Language: Studies in Ethnomethodology. Irvington, New York, pp. 97-121.

Goodwin, Charles, 1980. Restarts, pauses, and the achievement of a state of mutual gaze at turn-beginning. Sociological Inquiry 50 (3-4), $272-302$.

Goodwin, Charles, 2007. Environmentally coupled gestures. In: Duncan, S., Cassell, J., Levy, E. (Eds.), Gesture and the Dynamic Dimensions of Language. John Benjamins, Amsterdam/Philadelphia, pp. 195-212.

Haiman, John, 1980. The iconicity of grammar: isomorphism and motivation. Language 56 (3), 515-540.

Hakulinen, A., Vilkuna, M., Korhonen, R., Koivisto, V., Heinonen, T.R., Alho, I., 2004. Iso suomen kielioppi. Suomalaisen Kirjallisuuden Seura, Helsinki.

Heritage, John, 1998. Oh-prefaced responses to inquiry. Language in Society 27 (3), 291-334.

Heritage, John, 2002. Oh-prefaced responses to assessments: a method of modifying agreement/disagreement. In: Ford, C., Fox, B., Thompson, S. (Eds.), The Language of Turn and Sequence. Oxford University Press, Oxford, UK, pp. 196-224.

Inkelas, Sharon, Zoll, Sheryl, 2005. Reduplication: Doubling in Morphology. Cambridge University Press, Cambridge.

Israeli, Alina, 1997. Syntactic reduplication in Russian: a cooperative principle device in dialogues. Journal of Pragmatics 27 (5), 587-609.

Keevallik, Leelo, 2001. Estonian reduplication in action sequences. In: Niemi, J., Heikkinen, J. (Eds.), Nordic and Baltic Morphology: Papers from a NorFA Course, Tartu, June 2000. Studies in Languages, vol. 36. University of Joensuu, Faculty of Humanities, Joensuu, pp. 23-33.

Keevallik, Leelo, 2003. From Interaction to Grammar: Estonian Finite Verb Forms in Interaction. Acta Universitatis Upsaliensis Studia Uralica Upsaliensia 34, Uppsala.

Keevallik, Leelo, 2009. Üldküsimuse lihtvastuste funktsioonid. Keel ja Kirjandus 52 (1), 33-53.

Kiyomi, Setsuko, 1995. A new approach to reduplication: a semantic study of noun and verb reduplication in the Malayo-Polynesian languages. Linguistics 33 (6), 1145-1167.

Lakoff, George, Johnson, Mark, 1980. Metaphors We Live By. University of Chicago Press, Chicago.

Lerner, Gene, 1991. On the syntax of sentences-in-progress. Language in Society 20 (3), 441-458.

Lindström, Anna, 1999. Language as Social Action. Grammar, prosody, and interaction in Swedish conversation. Skrifter utgivna av institutionen för nordiska språk vid Uppsala universitet 46, Uppsala.

Lindström, Jan, 1999b. Vackert, vackert! Syntaktisk Reduplikation i Svenskan. Studier i nordisk filologi vol. 77. Svenska litteratursällskapet i Finland, Helsingfors.

Lindström, Jan, Linell, Per, 2007. Roli å roli. X-och-x som samtalspraktik och grammatisk konstruktion. In: Engdahl, E., Londen, A.-M. (Eds.), Interaktion och Kontext. Nio Studier av Svenska Samtal. Studentlitteratur, Lund, pp. 19-89.

Linell, Per, 2005a. Grammatical constructions in dialogue. In: Paper presented at the 9th International Pragmatics Conference, Riva del Garda, July $10-15$.

Linell, Per, 2005b. En dialogisk grammatik? In: Anward, J., Nordberg, B. (Eds.), Samtal och Grammatik. Studier i Svenskt Samtalspråk. Studentlitteratur, Lund, pp. 231-328.

Moravcsik, Edith A., 1978. Reduplicative constructions. In: Greenberg, J.H. (Ed.), Universals of Human Language, vol. 3. Word Structure. Stanford University Press, Stanford, pp. 297-334.

Ochs, Elinor, Schegloff, Emanuel A., Thompson, Sandra A. (Eds.), 1996. Interaction and Grammar. Cambridge University Press, Cambridge.

Raymond, Geoffrey, 2003. Grammar and social organization: yes/no interrogatives and the structure of responding. American Sociological Review 68 (6), 939-967.

Sacks, Harvey, Schegloff, Emanuel A., Jefferson, Gail, 1974. A simplest systematics for the organization of turn-taking for conversation. Language 50 (4), 696-735.

Schegloff, Emanuel A., 1996a. Confirming allusions: toward an empirical account of action. American Journal of Sociology 102 (1), $161-216$. 
Schegloff, Emanuel A., 1996b. Turn organization: one intersection of grammar and interaction. In: Ochs, E., Schegloff, E.A., Thompson, S.A. (Eds.), Interaction and Grammar. Cambridge University Press, Cambridge, pp. 52-133.

Schegloff, Emanuel A., 2007. Sequence Organization in Interaction: A Primer in Conversation Analysis, vol. 1. Cambridge University Press, Cambridge.

Sorjonen, Marja-Leena, 2001. Responding in Conversation: A Study of Response Particles in Finnish. John Benjamins, Amsterdam/Philadelphia. Sorjonen, Marja-Leena, Hakulinen, Auli, 2009. Alternative responses to assessments. In: Sidnell, J. (Ed.), Conversation Analysis: Comparative Perspectives. Cambridge University Press, Cambridge, pp. 281-303.

Stivers, Tanya, 2004. "No no no" and other types of multiple sayings in social interaction. Human Communication Research 30 (2), $260-293$. Stivers, Tanya, 2005. Modified repeats: one method for asserting primary rights from second position. Research on Language and Social Interaction 38 (2), 131-158.

Tannen, Deborah, 1987. Repetition in conversation: toward a poetics of talk. Language 63 (3), 574-605.

Tannen, Deborah, 1989. Talking Vocies: Repetition, Dialogue, and Imagery in Conversational Discourse. Cambridge University Press, Cambridge. Tannen, Deborah, 1990. Ordinary conversation and literary discourse: coherence and the poetics of discourse. In: Bendix, E.H. (Ed.), The Uses of Linguistics. Annals of the New York Academy of Sciences, vol. 583. The New York Academy of Sciences, New York, pp. 15-32.

Wierzbicka, Anna, 1986. Italian reduplication: cross-cultural pragmatics and illocutionary semantics. Linguistics 24 (2), $287-315$. 